\title{
공간정보기반 부동산거래선진화시스템 구축방안 Study on Modernized Real Estate Transaction System based on Spatial Information
}

\author{
조춘만* 정문섭** \\ Chun Man Cho $\cdot$ Moon Sub Chung
}

\begin{abstract}
요 약 우리나라는 1983 년 공인중개사 관련법을 최초로 도입하여 공인중개사를 중심으로 한 부동산거래문화 발전에 노력해왔다. 또한 국토교통부는 중개사협회 등 거래정보망 사업자를 일부 지정하여 매물정보의 신뢰성 및 거래의 투명 성 확보에 주력해왔다. 그럼에도 불구하고 부동산거래 자체에 대한 준법수준과 관행은 대부분 오랜 과거 복덕방 시절의 그것에서 크게 벗어나지 못한 실정에 놓여있다. 이러한 부동산 거래관련 후진적 행태는 국민의 중개업에 관한 신뢰성 등 사회적 자본(social capital)의 축적을 방해하며, 불필요한 사회적 추가비용이 발생되는 결과를 초래하고 있다. 즉, 중 개업자들에 의한 중개대상물에 대한 낮은 신뢰성과 그로 인한 투기적 가격상승 우려 및 시장왜곡 등이 지속적으로 발생 하는 결과에 일조하고 있다.

이러한 배경 하에, 본 연구의 목적은 국민에게 신뢰할 수 있는 부동산정보를 제공하고 효율적인 부동산거래를 지원하기 위한 공간정보기반 부동산거래선진화시스템의 모델 및 그 구축방안을 제시하는데 있다. 이를 통하여 우리나라 부동산 거래를 선진화하고 경쟁력 있는 부동산중개업 육성에 기여하고자 하였다.
\end{abstract}

키워드 : 거래정보망, 공간정보, 매물정보, 공부정보, 부동산거래, 부동산 전자상거래, 공인중개사

\begin{abstract}
Our country has made every efforts to develop Real Estate Transaction culture with emphasis on Licensed Realtors by introducing Real Estate Transaction Law in 1983. Also, MOLIT(Ministry of Land, Infrastructure and Transport) designated several organizations including KAR(Korea Association of Realtors) as Real Estate Transaction Information Network Licensees for data credibility enhancement and transaction transparency. Nevertheless, the level of law abiding spirit and transaction culture are still similar to those of the old 'Bokdeokbang' era. The under-developed transaction behaviors prevent the social capital of people's credibility on Licensed Realtors from advancing, and results in the outcomes of unnecessary social cost. That is, very low credibility on the data on Sales Items in the market and the fear of speculative real estate price uprise and market distortions are continuing on.

In this context, the purpose of this study is to propose the model of GIS-based Modernized Real Estate Transaction System and its execution policies to support credible Real Estate Information to the general public for efficient transactions in the market. Accordingly, the study aims at contributing to the modernization of Real Estate Transactions, fostering competitiveness of Realtors in the Real Estate Market.
\end{abstract}

Keywords : Transaction Information Network, Spatial Information, Sales Items Information, Register Information, Real Estate Information, Real Estate Transaction, Real Estate e-Commerce, Licensed Realtor

\section{1. 서 론}

\section{1 연구의 배경}

우리나라는 공인중개사법 제정('83.12) 이후 부동산 중개에 관한 그동안의 많은 제도개선의 성과에도 불 구하고 부동산거래 선진화 달성에 미흡한 실정에 있 다. 기획부동산 등 부동산 거래관련 일부 업체들의 편 법행위로 서민들에게 지속적 피해 발생과 함께 일부
중개업자들에 의한 거래상 불법행위도 여전히 지속되 고 있다. 이러한 부동산 거래관련 후진적 행태는 국민 의 중개업에 관한 신뢰성 등 사회적 자본(social capital) 의 축적을 방해하며, 불필요한 사회적 추가비용이 발 생되는 결과를 초래하고 있다. 즉, 중개업자들에 의한 중개대상물에 대한 낮은 신뢰성과 그로 인한 투기적 가격상승 우려 및 시장왜곡 등이 지속적으로 발생하 는 결과에 일조하고 있는 것이다.

\footnotetext{
* Chun Man Cho, Associate Research Fellow, Geospatial Info. Research Div., KRIHS. cmcho@krihs.re.kr (Corresponding author)

** Moon Sub Chung, Research Fellow, Geospatial Info. Research Div., KRIHS. mschung@krihs.re.kr
} 
이러한 부동산시장의 거래 신뢰성 회복과 투명성 확보를 위해서는 국민이 신뢰할 수 있는 부동산 매물 정보망 구축 및 운영이 필요하나, 부동산거래에 관한 매물정보, 시세정보, 부동산 공부정보 등을 통합적으 로 관리할 수 있는 시스템 또한 부재한 상황에 있다. 국가는 부동산거래정보망 제도를 도입('93)하여 중개 사협회가 정보망을 운영 및 관리하고 있으나, 기능저 하와 인지도 부족 등으로 그 활용이 미미한 상황에 있다. 실제로 중개사협회의 정보망에는 2012년초 기 준 약 5 만명의 가입자 수를 확보하고 있으나, 본 시스 템의 주요 활용목적은 편리한 부동산거래계약서 서식 다운로드 등이 더 우선시되는 상황에 있다. 정확하고 신뢰할만한 부동산매물정보에 대한 국민적 수요는 자 연스럽게 민간의 각종 부동산사이트와 주로 신도시지 역을 중심으로 자생적으로 발생한 사설정보망업체들 이 그 역할을 대신해왔다. 그러나 이러한 서비스들 역 시 진성매물 유통제약, 매물가격 임의 조정, 정보의 신뢰성 부족, 유료화 등에 의한 접근 제한 등으로 일반 시민이나 개별 중개업자들의 이용에 근본적인 한계가 있어왔다.

이와 더불어, 중앙정부의 온나라포털 등과 서울, 인 천 및 경기도 등 선도적 지방정부들에 의한 공간정보 기반 부동산정보포털 등이 구축 및 운영되고 있으나, 중개사와 시민들의 부동산거래절차에 이 시스템들을 원활하게 활용하지 못하는 상황에 있다. 즉, 한국토지 정보시스템(KLIS), 토지이용규제정보시스템(LURIS), 도시계획통합정보시스템(UPIS), 부동산거래관리시 스템(RTMS), 세움터 및 온나라포털 등 이미 공공부문 에서 부동산거래지원에 유용하게 사용될만한 개별 공 간정보시스템들을 구축 및 운영 중에 있다. 그러나 이 들 시스템들을 보다 사용자, 즉 중개사와 시민 그리고 공공행정의 입장에서 편리하고 유기적으로 연계 및 통합하여 제공하는 방향으로의 개선이 요구된다.

이러한 배경 하에, 본 연구의 목적은 국민에게 신뢰 할 수 있는 부동산정보를 제공하고 효율적인 부동산 거래를 지원하기 위한 부동산거래선진화시스템의 모 델 및 그 구축방안을 제시하는데 있다. 이를 통하여 우리나라 부동산 거래를 선진화하고 경쟁력 있는 부 동산중개업 육성을 도모하는데 기여하고자 하였다.

\section{2 기존 연구의 고찰}

부동산거래의 선진화를 위한 기존의 관련 연구들은 크게 부동산거래정보망의 필요성과 구축방안에 관한 연구, 부동산전자거래 활성화에 관한 연구 등으로 분
류할 수 있다. 본 연구의 내용과 방향성 등에 보다 가 까운 부동산거래정보망에 관한 주요 기존연구의 흐름 은 다음과 같다.

첫째, Choi[3]는 부동산거래정보망 관련 제도의 현 실적 실패원인을 파악하기 위하여, 이 제도를 성공시 키기 위한 전속중개계약 제도의 중요성과 등록된 부 동산정보의 대국민 신뢰성이 회복되어야 할 것 등을 강조하였다. 연구결과로서 부동산거래정보망의 전반 적 정보관리체계 정비, 중앙정부가 인식을 새롭게 하 여 거래정보망의 유용성에 대한 적극적 대국민 홍보 활동 등을 강조하였다.

둘째, $\operatorname{Kim}[7]$ 은 중개업자의 현실에 맞는 부동산거 래정보망 구축 및 활성화방안 모색을 위해 전문가 집 단심층면접(FGI) 및 중개사협회의 부동산거래정보망 의 발전방안을 제시하였다. 중개사협회, 학계, 연구소, 외국의 현황과 문제점을 참고하여 현실에 맞는 부동 산거래정보망을 활성화하기 위해 기존 문헌조사와 외 국현황 등을 분석을 병행하였다.

셋째, $\operatorname{Kim}[5]$ 은 현재의 부동산정보서비스의 문제점 등을 분석하여 개선안을 도출하고, 부동산 정보 수요 자 설문조사를 통하여 정보수요자가 필요로 하는 정 보서비스 모델을 제시하고자 하였다. 정보서비스 모 델을 찾기 위하여 국토교통부 온나라 부동산정보 통 합포털, 한국토지정보시스템(KLIS), KB국민은행 부 동산정보서비스 등의 문제점을 분석하고, 부동산거래 의 핵심적인 역할을 수행하는 부동산중개업자를 대상 으로 설문조사 등을 추가로 실시하였다.

넷째, Chae[1]는 중개업자에 의한 거래정보망의 편 리성, 유용성, 수익성, 만족도, 신뢰성 항목요인에 대 해 관련 변수를 선별하여 구조방정식모델을 이용하여 중개업자의 거래정보망 신뢰성을 세부 분석하였다. 분석결과에 따라, 중개업자는 거래정보망의 편리성, 유용성, 수익성에 불만족한 경향이 있고, 따라서 신뢰 성이 취약하므로 거래정보망 신뢰성 회복을 위한 정 책적 대안마련이 요구됨을 강조하였다.

본 연구는 부동산거래 선진화를 위한 통합정보시스 템 구현을 기존의 거래정보망 발전에 국한하지 않고, 부동산거래절차 전체를 하나의 프로세스로 규정하고, 거래전, 거래시 및 거래후로 분류하여 중개업자와 시 민 그리고 정책결정자의 입장에서 모두 활용할 수 있 는 부동산거래선진화시스템의 모델수립 및 추진방안 을 제시하고자 하였다. 


\section{2. 국내외 부동산거래정보망 추진현황과 시사점}

\section{1 우리나라의 추진현황}

부동산거래정보망이란 중개업자* 상호간에 컴퓨 터통신망을 이용해 각종 부동산 관련 매물정보를 공 유 및 공동 중개하는 정보시스템을 말한다. 이 용어는 1907년 미국에서 처음으로 MLS(Multiple Listing Service) 의 개발로 시작되어 1920 년대 본격적으로 발달하기 시작한 개념이다[8]. 우리나라도 이미 현행 '공인중개 사의 업무 및 부동산거래신고에 관한 법률 제 24 조 제 1 항'에서 거래정보망의 성격을 이미 규정하고 있다. 현 재 국내에서 운영 중인 부동산거래정보서비스는 모두 민간주도로 이뤄지고 있으며, 크게 포털사이트, 부동 산정보사이트, 스마트폰 어플, 지역중심 사설정보망 그리고 국토부 지정 부동산거래정보망 등으로 나뉜 다. 포털사이트(네이버, 다음 등), 부동산정보사이트 (부동산 114 , 부동산써브, $\mathrm{KB}$ 부동산알리지 등)와 사설 정보망(한국공인중개사협회의 기존 탱크21) 등이 여 기에 속한다.

애초에 정부는 1994년부터 전속중개계약제도를 도 입하여 국토부 지정 거래정보망의 정상운영을 목표하 였으나 실제 기능을 제대로 수행하지 못하는 반면, 민 간부문의 은행과 부동산정보제공업체 등이 정보제공 의 주도적 역할을 유지해온 상황에 있다. 국민은행, 부동산114, 스피드뱅크 등은 전국가맹점을 통한 시세 조사로 업소 당 소정의 비용을 지급하고, 총합정보는 중개업소 광고를 목적으로 무상 제공하는 등의 서비 스들이 유통되고 있다.

\section{2 미국의 추진현황}

미국에서 부동산 소유자가 부동산을 매각하고자 할 때는 부동산회사 또는 부동산브로커(즉, 중개사)와 부 동산매각대행계약을 맺게 되어 있다. 대행계약을 체 결한 부동산회사나 브로커는 각자 보유한 매물리스팅 공유를 목적으로 MLS(Multiple Listing Service)를 조 직적으로 운영한다. MLS는 다수 회원 간 공동중개의 형태로서, 미국전역 1,400여개 지방의 지역지회(Local Board of Realtor)를 통해 각 지역정보를 유통하고 있 다(Figure 1).

* 중개업자란 '공인중개사의 업무 및 부동산거래신고에 관 한 법률' 제 2 조 4 항에 의하여 중개사무소의 개설등록을 한 자를 말함
부동산중개업자(Broker) 또는 판매보조원(Sales Person) 을 회원으로 하는 전미공인중개사협회(NAR; National Association of Realtors)에는 약 90 만 명의 회원이 있 으며, 이중 $94 \%$ 가 MLS에 가입되어 있다[6]. 부동산 중 주택의 경우 전체 매매건수의 $85 \%$ 가 중개업자를 통해 이루어지며 이 중 $80 \%$ 가 $\mathrm{MLS}$ 를 이용하는 것으 로 조사되고 있다.

실제로 현재 미국 MLS제도(일본 REINS제도 등 포 함)에서는 중개계약의 대부분이 전속 또는 독점중개 계약**을 통해 이루어지고 있다[10]. 미국은 중개업자 를 통하는 거래의 대부분이 MLS를 이용하며 실제 주 택거래의 $90 \%$ 이상이 MLS를 통하여 이루어지며, 이 는 독점 및 전속중개계약 제도가 정착되었기 때문에 가능하다[4].

\section{3 일본의 추진현황}

일본은 인터넷의 발달로 부동산중개업자의 지리적 영업범위 한계를 극복하게 함으로써 전국을 대상으로 영업을 할 수 있게 되어, 부동산정보에 대한 독점적인 지위에서 벗어나 상호협력을 유도하게 되어 REINS (Real Estate Information Network System, 부동산유통 표준정보시스템)가 등장하게 되었다. 부동산거래 물 건을 등록시키고 이를 검색하여 유통시키는 공적 전 산망으로 수요자가 원하는 부동산을 부동산 업자에게 의뢰하면 REINS를 통해 파악하여 소개해준다(Figure 2).

1986년 12월 동경 부동산 조합 부동산 유통센터를 처음으로 지정한 것을 시작으로 1990년 3월까지 34개 의 유통기구에 대해서 모델지정을 수행하였다. REINS

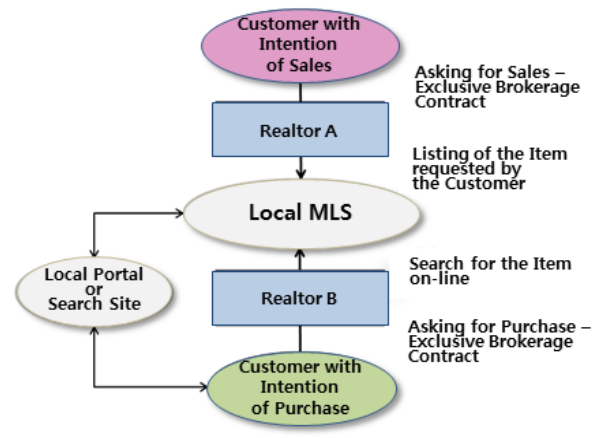

Figure 1. MLS-based Real Estate Transaction

전속중개계약은 피의뢰 중개사가 소개한 상대방과만 거 래계약이 가능하나, 독점중개계약은 피의뢰 중개사가 소 개한 상대방 이외와도 계약을 채결할 수 있음 
의 보급 등 부동산 유통기구의 정비 및 근대화를 배경 으로 1988년 5월에 부동산 중개업법의 개정이 이루어 지면서 일반매매계약에서 전속전임매매계약제도가 창설되었다. 전속전임 매매계약을 체결한 의뢰자는 거래 당사자들이 거래의 상대방을 발견하는 것이 금 지되는 대신 부동산 중개업자의 특별한 의무가 법령 상 부가되고, 건설성 장관이 지정하는 유통기구(지정 유통기구)에 물건 등록 의무가 부가되었다.

1988년 택건업법 개정에 의해 도입된 지정유통기구 는 1990년부터 전국 37권역에서 회원업자를 온라인 으로 연결하여 물건의 등록검색을 행했다. 이들 37 개 권역별(수도권, 근기권, 중부권, 그 밖의 각 현)로 1 개 씩 지정된 지정 유통기구에 의해 운영되고 지정유통 기구는 1995년 법개정으로 1995년 4월에 4기구로 통 합되어 현재 전국에서 약 10 만 명의 업자가 가입되어 있다. 이는 실제 택지건물거래업자의 약 7할 이상에 해당 하며 지정유통기구에 의한 부동산정보의 교환은

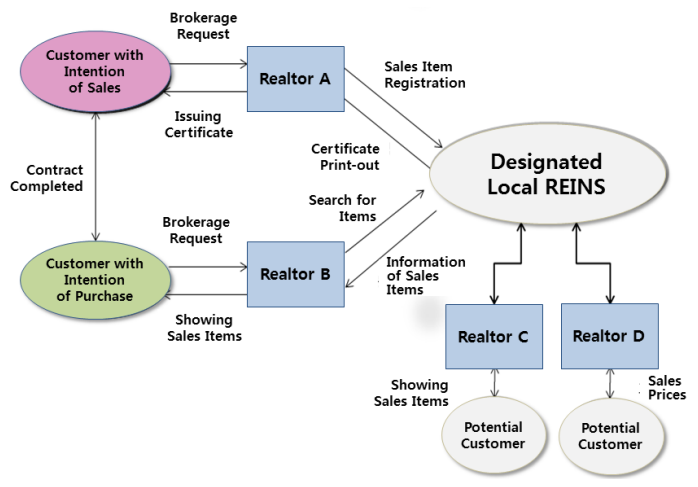

Figure 2. REINS-based Real Estate Transaction

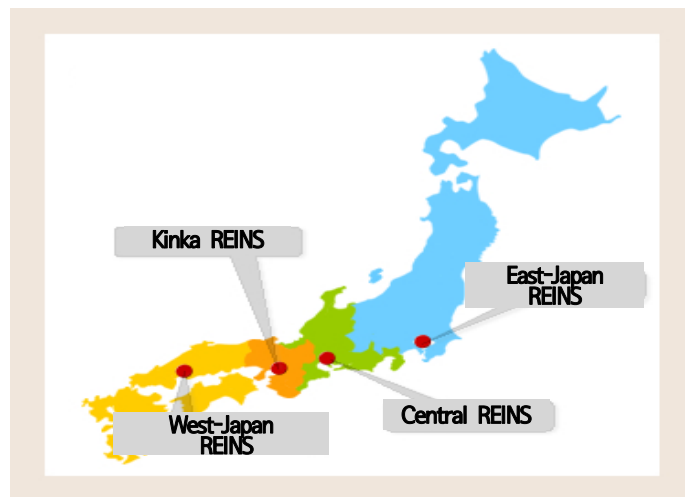

Figure 3. Locations and Allocated Areas of Real Estate Information Distribution Centers Source: http://www.reins.or.jp
REINS를 통해서 가능하다(Figure 3).

REINS를 기반으로 한 각 지역의 지정유통기구는 부동산거래 관련 데이터, 거래가격, 수급 상황 등의 부동산 시장의 동향을 신속히 파악하여 국민들에게 정확한 자료를 제시해주고 있다. 거래의 공정성과 투 명성을 확보하고 합리적인 부동산 가격 형성을 촉진 한다는 관점에서 REINS의 데이터는 매월 공표되고 있다. 일본의 거래정보망은 민간기업의 자율 경쟁에 의해 운영되고 있는 우리나라의 거래 정보망과 달리 운영 주체의 지정 및 자료의 이용 등에서 공적 성격이 매우 강조되고 있다.

\section{4 추진현황 시사점}

부동산거래정보망에 관해 가장 선도적 발전과 데이 터의 정책적 활용의 성공적 사례에 해당하는 미국과 일본의 현황조사를 통한 시사점을 도출하였다. 이를 바탕으로 우리나라 부동산거래선진화시스템 구축의 개선방향 설정에 활용하였다.

첫째, 미국과 일본의 경우 전속중개계약과 독점중 개계약이 보편화되어 있어 중개업자는 안전하게 거래 정보망에 상세정보를 등록할 수 있고, 보수도 보장 받 고 있어 매우 안정적인 제도적 기반 하에 있다.

둘째, 미국과 일본 모두 지역별로 거래정보망이 분 화되어 있고, 하나의 전국망으로 통합되어 운영되고 있다. 특히 REINS는 물건정보 규격을 통일시켜 프로 그램 적용하여 표준화를 위한 기능을 제공하고 있다.

셋째, 전국망에 취합된 자료는 부동산물건 종류별 로 거래건수, 거래금액, 매물등록건수 등 거래현황과 거래자료 등을 제공하고 있다. 이러한 거래 자료는 시 세 및 시황 등의 부동산자료로 생산되어 주기적으로 공표하고 있어 부동산시장 신뢰성 유지에 기여한다.

넷째, 미국의 MLS의 경우 프로그램사용 교육과 MLS 데이터베이스 사용법을 만들어 이용자들이 편 리하게 사용할 수 있도록 지원하고 있다. 미국과 일본 모두 중앙 주도적으로 거래정보망을 표준화하여 지역 망을 운영하고 있으며, 하나의 전국망으로 통합하여 부동산정보를 취합하는 시스템으로 운영되고 있다.

다섯째, 거래정보망에 취합된 부동산가격정보를 가 공하여 시장분석자료와 특정지역의 시장동향을 지역 별로 세분화하여 다각적인 관점에서 분석하여 발표하 고 있다. 이 자료를 정부의 부동산정책 자료로 활용하 고 있으며, 우리나라도 공익적 차원에서 부동산가격 정보를 효율적으로 취합하고 활용할 수 있는 방안의 모색이 요구된다. 


\section{3. 부동산거래선진화시스템 구축의 기본 방향}

\section{1 접근방법}

국내외 부동산거래지원시스템의 추진상황을 살펴 본 결과, 우리나라 부동산거래체계는 거래사이클 상 실거래가 신고 전 거래이전 절차(즉, 매물검색 및 중개 의뢰 등)의 정보시스템기반 선진화가 매우 취약하다. 따라서 기존의 부동산매물정보망(과거 '거래정보망' 이라 불림)의 소극적 대처에서 탈피하여, 1)매물정보 망, 2)부동산거래절차의 전자적 표준화, 3)과학적 부 동산정책지원 등 종합 틀에서 부동산거래선진화시스 템을 구현하고자 하였다. 이에 따라, 부동산거래에 관 한 현재 문제점들을 거래전, 거래시 및 거래후로 분류 하고, 각 단계별 문제점에 관한 개선방향을 도출하였 다. 또한 각 단계별 개선점들을 정리하고 그 구현을 위한 단계별 개선방향을 기반으로 부동산거래선진화 시스템의 서브시스템을 1)부동산정보유통시스템, 2) 부동산안전거래시스템, 3)부동산정책지원시스템으로 제시하였다(Table 1).

\section{2 기본구상}

부동산거래선진화시스템 구현을 위한 '부동산거래 선진화 사회의 구현'의 비전 하에, 본 시스템의 서비스 계층을 국민, 공인중개사 그리고 정부로 규정하였다.
국민을 위해서는 안전하고 편리한 부동산거래문화를 정착하고, 공인중개사의 위상을 선진국 수준으로 높 이며, 국가는 시의적절한 부동산정책수립을 지원하는 것을 목표로 하였다. 세부 추진전략은 크게 1) 응용시 스템 구축과 2) 하부 기반인프라 조성으로 보았고, 앞 서 제시된 3 대 서브시스템과 더불어서, 기반인프라로

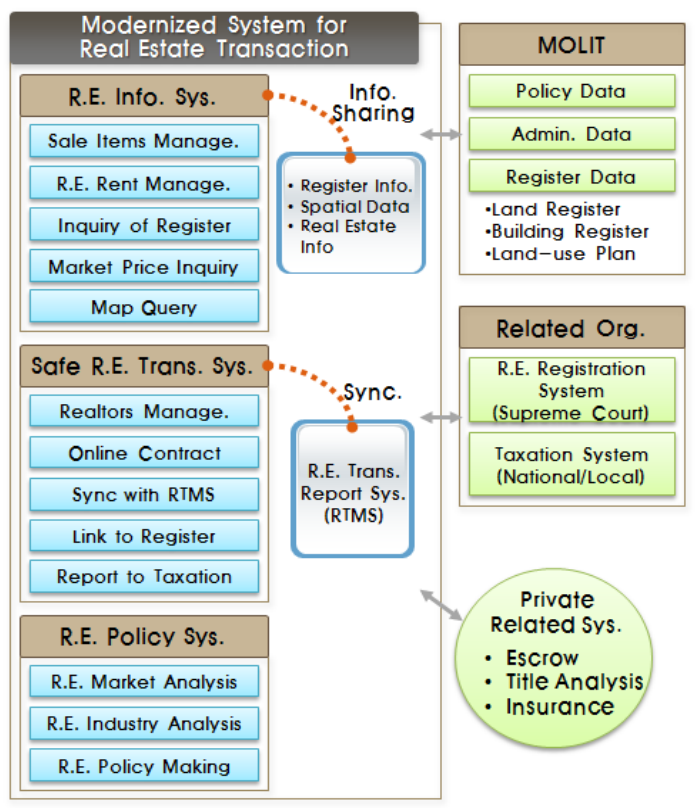

Figure 4. Target System Concept

Table 1. Problems and Improvement Direction by Real Estate Transaction Steps

\begin{tabular}{|c|c|c|c|}
\hline & Before Transaction & During Transaction & After Transaction \\
\hline$\frac{\sigma}{\overrightarrow{0}}$ & $\begin{array}{l}\text { - Low Credibility on Sales Information } \\
\text { - Inevitable Contacts of Multiple } \\
\text { Realtors for Regular Sales } \\
\text { - Closed and Exclusive Management } \\
\text { of Sale Items by Limited Number } \\
\text { of Realtors }\end{array}$ & $\begin{array}{l}\text { - Illegal Contracts possible such as } \\
\text { Upper/Lower Price Report and } \\
\text { Multiple Contracts Writing } \\
\text { - Unnecessary Visit to 'Gu' Office } \\
\text { for each Transaction Contract Reporting } \\
\text { - Unconnected to Report to Registration } \\
\text { and Taxation }\end{array}$ & $\begin{array}{l}\text { - Unclear and Insufficient Market Data } \\
\text { for Public Policy for Real Estate } \\
\text { - Lack of Credible Information for the } \\
\text { Citizen's Decision Making on Real } \\
\text { Estate } \\
\text { - Less Standardized System for Regular } \\
\text { Training of Realtors }\end{array}$ \\
\hline 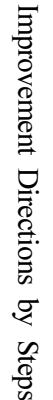 & $\begin{array}{l}\text { - Construction of Real Estate Infommation } \\
\text { Network System } \\
\text {-Open Sales Information } \\
\text {-Exclusive Transaction } \\
\text {-Comprehensive Information } \\
\text {-Fraud Sale Items Filtering } \\
\text { - Link to Official Register Info. } \\
\text {-Comprehensive Real Estate Register } \\
\text { Info.('Ilsapyonri') } \\
\text { - Realtors Management }\end{array}$ & $\begin{array}{l}\text { - Construction of Safe Real Estate } \\
\text { Transaction System } \\
\text {-Electronic Contract } \\
\text { - Link to RTMS } \\
\text {-also to Registration System(IROS), } \\
\text { National and Local Taxation System } \\
\text { - Automatic Fill-out of Sales Item } \\
\text { Condition Report }\end{array}$ & $\begin{array}{l}\text { - Construction of Real Estate Policy } \\
\text { Support System } \\
\text {-Real Estate Analysis System } \\
\text {-Housing Policy Support } \\
\text {-Trends Analysis } \\
\text { - Establishment of Brokerage Modernization } \\
\text { Center } \\
\text {-Policy for Fostering Real Estate Brokerage } \\
\text { - Support for Regular Training }\end{array}$ \\
\hline
\end{tabular}


서 관련DB 연계통합, 표준화, 민관협력 거버넌스 그 리고 법제도기반 정비로 설정했다(Figure 5).

\section{3 목표시스템 개념도}

\subsection{1 부동산정보유통시스템}

부동산정보유통시스템은 부동산거래에 필요한 믿 을만한 부동산매물정보와 공적장부 정보를 제공하여, 중개사와 시민들에게 편리하고 안정적인 부동산거래 행위를 지원하는 시스템으로 구축한다. 부동산 공부 정보는 주로 부동산종합증명('일사편리')과 연계체계 를 구축하여 신뢰성 있는 정보기반 시민의 거래의사 결정과 중개사의 편리한 물건조서 작성과 각종 서식 작성 등을 지원할 수 있도록 구축한다. 그러나 일사편 리는 기존에 개별 구축된 18 종 부동산관련 공부증명 을 통합한 것으로서, 정보의 깊이나 종류 그리고 업데 이트 주기 등의 측면에서 제약이 있을 수 있다. 따라서 부동산거래과정에서 요구되는 공공정보의 실수요 충 족을 위해서는 실제 지자체 시·도를 기반으로 한 부 동산 행정정보체계와의 연계를 중장기적으로 모색해 야 보다 성공적인 부동산거래지원이 가능할 수 있다.

\subsection{2 부동산안전거래시스템}

부동산거래 과정에 있어서 거래계약서 작성에 관한 여러 가지 사고가능성과 불편을 방지하여 편리하고 안전한 계약절차를 지원하기 위하여 서식자동작성과 온라인 계약절차를 지원하는 시스템이다. 이와 더불 어, 중개사들의 계약절차 상 가장 주요 불편사항 중 하나인 실거래가 신고와 이와 연동된 등기 및 세금신 고를 연계하여 계약 및 거래완료(즉, 잔금완료)와 함 께 자동 연쇄처리를 구현한다. 또한 현재 한국토지정 보시스템(KLIS)에서 제공하는 중개인 관리시스템과 연계하여 중개인 정보관리를 통합적으로 가능하도록 구축한다.

\subsection{3 부동산정책지원시스템}

중개사의 효과적인 시장동향 파악과 시민들의 부동 산거래 의사결정에 요구되는 다양한 분석통계자료와 유통가격지수, 부동산수요/공급량, 임대차계약상황 등을 제공하여 중개사의 중개행위와 일반시민의 거래 의사결정을 위한 과학적 정보기반을 제공한다. 또한 정책의사결정자로 하여금 시장상황에 적절히 대응한 부동산정책수립과 처방 등이 가능하도록 지원한다 (Figure 5).

\section{4 부동산 관련 공간정보 연계}

부동산 거래에 요구되는 관련 공부정보의 출처와 연계관계는 1) 국토교통부 단독서버 구축과 2) 광역시 도 레벨의 지역서버 구축의 경우로 적용이 가능하다.

먼저 광역시도 레벨의 지역서버를 분산 구축하여 시스템을 구축 및 운영할 경우 관련 정보 및 각 출처들 과의 연계관계는 Figure 6의 내용과 같이 국토교통부 공간정보오픈플랫폼을 통하여 제반 공간정보를 자료 수신하여 활용할 수 있다. 국토교통부부 KLIS와 자료 연계를 통하여 토지이용계획도의 Web Service와 연계 할 수 있다. 건축물대장 요약자료는 세움터로 실시간 연계할 수 있고, GIS기반 건물 통합정보를 취득할 수 있다. 또한 각 지자체의 KLIS로부터 연속지적도, 개별 공시지가와 토지특성도, 부동산 중개업무 및 토지거 래허가 내역을 자료 수신할 수 있고, 각 지자체의 RTMS로부터 건축물대장을 실시간 연계한다.

한편, 국토교통부에 단독 중앙서버를 설치하여 부 동산거래선진화시스템을 구축 및 활용할 경우 이상의 모든 공부자료는 온나라 또는 부동산행정정보일원화

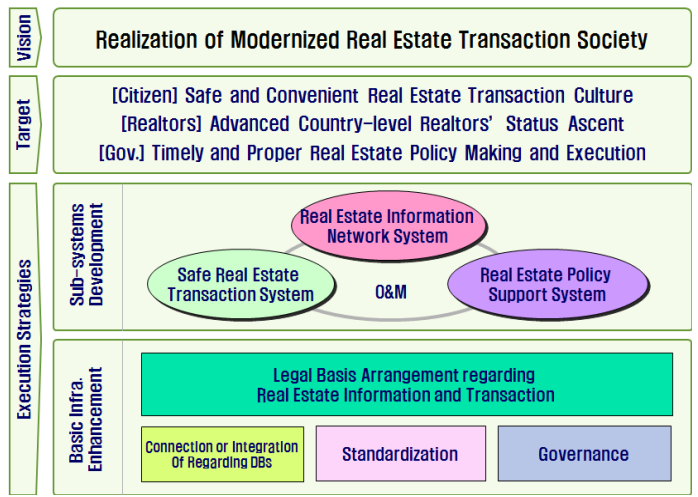

Figure 5. Basic Plan for Modernized Trans. System

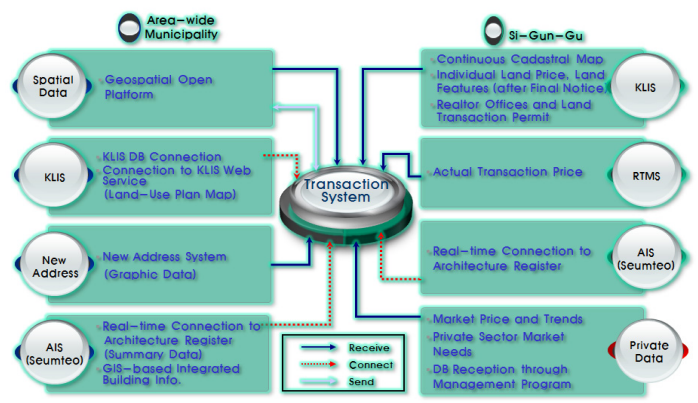

Figure 6. Geospatial Data Connection regarding Real Estatate 
시스템(일명 '일사편리')과 연계하여 사용할 수 있다. 이 경우, 기존 부동산거래관리시스템(RTMS) 중앙서 버와 본 부동산거래선진화시스템은 통합적으로 운영 관리할 수 있는 장점이 있다.

\section{5 단계별 구축절차}

1 단계는 신뢰할 수 있는 매물정보망과 부동산 공부 자료를 연계구축하는 단계로서, 부동산정보유통시스 템을 구축하고 부동산 공적자료 및 중개업 자료를 연 계하여 물건조서의 신뢰도를 향상시킨다. 또한 자료 제공의 용이성을 확대하여 부동산매물정보 등록 및 관리 관련 법제도의 개선 및 조정을 추진한다.

2단계는 1단계에서 구축된 매물정보망 및 공부자료 연계체계의 기반위에 RTMS를 연계구축하는 단계로

Table 2. Detailed Projects by Stages

\begin{tabular}{|c|c|c|c|}
\hline \multicolumn{2}{|c|}{ Stages } & & Detailed Contents \\
\hline & \multirow{2}{*}{ 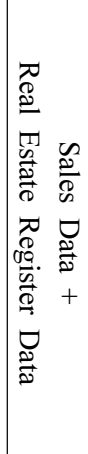 } & $\begin{array}{l}\text { R.E. Info. } \\
\text { Network } \\
\text { System }\end{array}$ & $\begin{array}{l}\text { - Construction of Real Estate } \\
\text { Information Network System } \\
\text { - Connection to Real Estate Public } \\
\text { Register Data } \\
\text { - Connection to Realtor Offices Data }\end{array}$ \\
\hline & & $\begin{array}{c}\text { Legal } \\
\text { Basis } \\
\text { Research }\end{array}$ & $\begin{array}{l}\text { - Real Estate Sales Information } \\
\text { Registration and Management } \\
\text { - Legal Designation of Public Sales } \\
\text { Information Network } \\
\text { - Public Opening of Real Estate } \\
\text { Sales Items Information }\end{array}$ \\
\hline \multirow[t]{2}{*}{ 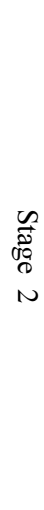 } & \multirow{2}{*}{ 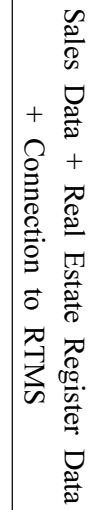 } & $\begin{array}{l}\text { Safe R.E. } \\
\text { Transactio } \\
\text { n System }\end{array}$ & $\begin{array}{l}\text { - Construction of Safe Real Estate } \\
\text { Transaction System } \\
\text { - Connection to RTMS } \\
\text { - Connection to Registration Office } \\
\text { and Taxation Office(national/local) } \\
\text { - Internet Access for Realtors to } \\
\text { Online Sales Contract Writing }\end{array}$ \\
\hline & & $\begin{array}{c}\text { Legal } \\
\text { Basis } \\
\text { Research }\end{array}$ & $\begin{array}{l}\text { - Applying Realtor Office Permit } \\
\text { - Online Contract Writing } \\
\text { - Direct Reporting to RTMS } \\
\text { - Direct Reporting to Registration } \\
\text { and Taxation Offices }\end{array}$ \\
\hline 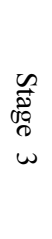 & 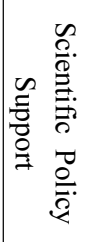 & $\begin{array}{l}\text { R.E. } \\
\text { Policy } \\
\text { Support } \\
\text { System }\end{array}$ & $\begin{array}{l}\text { - Construction of Real Estate Policy } \\
\text { Support System } \\
\text { - Construction of Brokerage Promotion } \\
\text { Center } \\
\text { - GIS-based Real Estate Market } \\
\text { Analysis Tools Development }\end{array}$ \\
\hline
\end{tabular}

서, 매 계약건마다 실거래가 신고를 위해 중개사의 구 청방문 등 번거로움을 해소한다. 또한 등기소 및 세무 관련 시스템까지 연계를 확대하여 등기와 세무를 한 꺼번에 해결하여 매물검색-계약-신고의 전체 프로세 스를 일거에 해결토록 지원한다.

마지막으로, 3 단계는 과학적 부동산정책지원을 위 한 정책지원시스템을 구축 및 운영하는 단계로서, 앞 서 개발 및 운영될 양대 서브시스템들에 축적되는 빅 데이터를 분석 및 정책에 활용토록 한다. 즉, 부동산매 물 $\mathrm{DB}$, 부동산공부DB 및 부동산거래DB 등 축적 정보 들을 종합 분석하여 과학적인 부동산정책을 지원하 며, 동시에 부동산 중개업 육성을 위한 중계센터를 구 축 및 운영한다(Table 2).

\section{4. 주요 실행계획}

\section{1 유형별 시스템개발 방법}

\subsection{1 신규개별형 VS. 기존 RTMS 발전형}

부동산거래선진화시스템은 전면 신규개발 또는 기 존 RTMS를 업그레이드하는 발전형으로의 개발을 고 려해볼 수 있다. 특별히 RTMS 발전형의 경우는 시스 템서버를 신규로 구축하지 않고 기존에 국토교통부가

Table 3. Pros \& Cons between New Development and RTMS Upgrade

\begin{tabular}{|c|c|c|}
\hline & New Development & RTMS Upgrade \\
\hline Pros & $\begin{array}{l}\text { - Provision of } \\
\text { Fundamental Basis for } \\
\text { Real Estate Transaction } \\
\text { Modernization } \\
\text { - Simple and Low-cost } \\
\text { Connection to Register } \\
\text { ('IlsaPyonri') } \\
\text { - Easy and Simple System } \\
\text { Operation and } \\
\text { Management }\end{array}$ & $\begin{array}{l}\text { - Easier Provision of Real- } \\
\text { time Register Data from } \\
\text { Local Municipalities } \\
\text { - No or Lower Cost of } \\
\text { System Construction by } \\
\text { Using Existing RTMS } \\
\text { - Easier Transaction Report } \\
\text { using RTMS } \\
\text { - Legal Basis acquired }\end{array}$ \\
\hline Cons & $\begin{array}{l}\text { - Additional Construction } \\
\text { Cost by more than } 20 \% \text {, } \\
\text { compared with RTMS } \\
\text { Upgrade } \\
\text { - Additional Construction } \\
\text { Cost of Additional } \\
\text { Systems Development } \\
\text { for Local Municipalities } \\
\text { - No Legal Basis }\end{array}$ & $\begin{array}{l}\text { - In Principle, RTMS is } \\
\text { for Public Admin. } \\
\text { System using Public } \\
\text { Comm. Network } \\
\text { - Difficulty of Public and } \\
\text { Private Data Manage. } \\
\text { and Data Safety } \\
\text { - Relatively Complex } \\
\text { System Structure } \\
\text { - Possibility of System } \\
\text { Redevelopment }\end{array}$ \\
\hline
\end{tabular}


보유한 RTMS 중앙서버와 전국의 시·도 기반 지역서 버 네트워크를 활용하여 전체 사업비 투자규모와 사 업기간 상 이점을 예상할 수 있다. 신규개발형과 기존 RTMS 발전형 간 고려해야 할 장점과 단점은 <Table 3> 의 내용과 같다.

\subsection{2 중앙집중형 VS. 광역분산형}

기존 유사시스템을 활용하지 않고 완전히 신규로 부동산거래선진화시스템을 구축할 경우, 시스템서버 의 중앙집중형 또는 각 지역의 광역시 · 도 기반의 광 역분산형으로 개발할 수있다. 신규개발 중앙집중형과 광역분산형 간 고려해야 할 장점과 단점은 다음과 같 이 예상해 볼 수 있다.

첫째, 집중형은 단일시스템을 구축함으로써 일사편 리, RTMS 등 기타 시스템들과 연계가 용이한 장점이 있고, 분산형은 그 반대의 경우에 해당한다.

둘째, 집중형은 단일서버만 관리하면 되므로 시스 템유지관리가 쉽고 비용이 절감되는 장점이 있다.

셋째, 집중형은 전국적 동시접속이나 과부하 등에 따른 시스템 성능저하 우려가 있을 수 있으나, 분산형 은 비교적 과부하문제에서 자유롭다.

넷째, 집중형은 통합관리로 인해 일개 시스템에 문 제발생시 전체 유관시스템에 영향을 미칠 수 있는 반 면에, 분산형은 그 반대의 경우에 해당한다.

다섯째, 집중형에 비해 광역분산형은 지자체별 자 세한 실시간 공부정보 연계로 상세정보의 제공이 가 능하나, 지역분선에 따른 추가비용이 발생할 수 있다.

요컨대, 전체시스템의 안정적 운영 및 상세자료 측 면 에서는 광역분산형 시스템으로 구현해야하나, 비 용대비 효과의 측면과 유지보수 편의성과 조기구축
및 활용의 측면에서 중앙집중형을 고려해볼 수 있다.

\section{2 개발사업의 추진체계}

부동산거래관련 정책에 관한 주관부처로서 국토교 통부 주택토지실 토지정책관의 주도 하에 시스템 개 발에 관한 사업을 맡아 추진할 수 있는 전담 추진기관 을 외부에 지정하여 부동산거래선진화시스템의 개발 및 관리의 전체 프로세스를 체계적으로 추진토록 한 다. 각 단계별 사업의 특성을 고려하여 사업주관, 추진 자문, 사업추진 및 개발 등의 분야별 세부 기관을 규정 하면 Figure 7와 같다. 국토교통부에 '부동산거래선진 화 정보화사업추진위윈회'를 신설하여 사업심의 및 승인 등을 하고, 부동산정보 관련 관계 국책연구기관 을 사업수행 전담기관으로 지정과 함께 시스템개발 추진을 위한 제도정비팀, 시스템개발팀, 실무지원팀 으로 세분화할 수 있다.

개발 3 단계를 통해 부동산거래선진화센터를 개소 하여 부동산정책지원시스템 구축 및 중개사진흥 기능 을 추가해야 하는데, 본 시스템센터의 운영관리를 위 해서는 1) 국토부내에 센터를 신설하거나, 2) 부동산 정보 관련 국책연구기관 중 한곳을 지정하여 센터를 설립토록 할 수 있고, 또는 3) 공익목적의 재단법인을 설립하여 민관협력 자본에 의한 센터설립이 가능하다.

이와 유사한 실제사례로는 일본의 부동산유통근대 화센터와 국토부의 건설산업정보센터 등이 있다.

\section{3 시스템의 중장기 발전방향}

일반적인 부동산거래의 절차는 크게 정보검색, 중 개의뢰, 계약체결, 대금납부, 소유권이전등기, 과세절

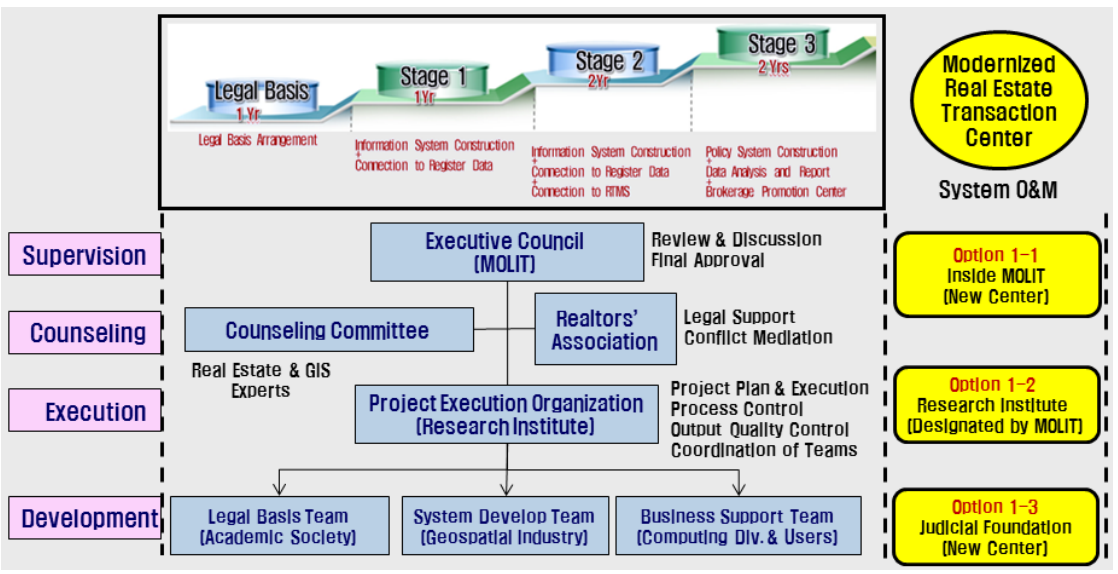

Figure 7. Project Execution Organization Designation Type 
차에 이르는 전체 과정을 포괄하면 이와 같이 정리할 수 있다.

전체 부동산거래 절차를 고려하여 우리나라에 각 절차별로 이미 구축 및 운영 중인 부동산거래관련 정 보시스템 현황을 분석해보면, 금융거래서비스(즉, 계 약금/중도금/잔금지불 그리고 각종 세금납부) 및 일반 거래가 아닌 경공매 입찰과 분양거래 서비스에 대한 시스템 기반 정보화가 과제로 남아있다. 이들을 중장 기적으로 연계·통합한 부동산거래선진화시스템의 발전방향은 당장 시스템을 구축한다고 할 경우, 단기 적으로는 2018년까지 부동산거래 절차상 경공매 임대 분양과 금융거래 그리고 세금납부의 모든 절차에 간 한 기존 시스템들과 연계 또는 통합을 모색할 수 있다. 또한 중기적으로 2020 년까지는 마켓에서의 부동산 생 애주기 전체를 생성, 유통 및 폐기단계로 포괄하는 전 체 프로세스를 공공관리시스템으로서 지자체별 '통합 부동산유통관리체계'로 발전시킬 수 있다.

\section{4 이해관계자간 실질적 협력방안}

부동산거래선진화시스템의 핵심은 매물정보와 공 부정보의 연계에 있으며, 이는 수익사업이 아닌 부동 산 유통을 촉진함으로써 부동산산업발전과 국민의 편 익을 증진하기 위한 공익사업으로 자리매김해야 한 다. 더불어 부수적으로는 부동산거래질서 확립과 정 책에 필요한 실질적 시장정보의 수집 등의 효과도 예 상할 수 있다. 따라서 부동산거래선진화시스템은 공 익사업 목적으로 하는 민관협력적 재단법인(가칭, '한 국부동산유통진흥원')의 형태를 종국적으로는 추구 해야 하며, 공공과 민간의 상호 호혜적 이익을 나눌 수 있는 제도기반의 명확한 비즈니스모델의 제시를 통해 본 시스템과 여러 이해관계자간 실질적 협력방 안 마련이 요구된다. 이러한 접근방법에 의한 본 시스 템과 기존의 부동산거래관련 각 이해관계자간 협력방 안의 요점은 다음과 같다.

\subsection{1 중개사협회 관련}

기존 중개사협회가 보유하고 있는 거래정보망(탱크 21, 2014년부터 '한국부동산거래망-KREN' 오픈예정) 의 업그레이드를 통한 보다 경쟁력 있는 국민부동산 정보포털로 고도화하기 위해서는 1) 기존 매물정보망 에서 온라인거래시스템化, 2) 공부정보의 연계, 3) 실 거래가신고 등 계약완료후 후속절차 동기화 등이 요 구된다. 그러나 민간기관으로서의 제약을 극복하고 이상의 성과를 이루기 위해서는 민·관 협력적 '부동
산거래선진화시스템'의 우산 하에 협회와 국가 주관 부처 간 유기적 시스템연계가 요구된다.

이를 위해서는 협회가 추구하는 매물정보망(KREN) 기능이 본 선진화시스템의 3 대 서브시스템 중 '부동산 정보유통시스템'으로 수렴하여, 이를 통해 신뢰할 수 있는 매물정보와 공부정보를 적절히 융합한 협회의 소기의 목적을 달성할 수 있다. 그 구현하기 위해서는 협회-국토부 협력하에 '국가표준 부동산거래선진화 시스템'을 구축하고, 중앙에 반관·반민의 '(가칭)한 국부동산유통진흥원'을 설립하여 그 안에 선진화시스 템 중앙서버를 설치해야 한다. 또한 각 지역별 중개업 소 관리기능을 가진 KLIS를 운영·관리하는 시·도별 ‘지역부동산유통기구'에 선진화시스템 지역분산서버 를 설치하여, 각 지역별 매물 $\mathrm{DB}$ 와 공부정보가 중앙서 버에 유기적으로 연결되어야 한다. 이러한 지역별 $\mathrm{DB}$ 는 각 지역별 '지역부동산유통기구'를 기반으로 부동 산시장 진단과 처방을 위한 정책수립에 활용될 뿐만 아니라, ‘(가칭)한국부동산유통진흥원' 내 중앙서버로 집적되어 부동산관련 과학적 정책수립에 기여할 수 있는 발판이 마련된다.

이와 같은 사례는 미국의 MLS와 일본의 REINS에 서 동일하고 발견되며, 단지 차이점은 미국의 경우 중 앙의 전국부동산협회(NAR; National Association of Realtors)가 국가표준 MLS시스템을 구축 및 각 지역 별 중개사협회 지회(Local Board of Realtors)가 자율 적으로 표준 MLS를 매개로 매물 $\mathrm{DB}$ 관리를 하도록 한 다. 반면, 일본은 반관 - 반민의 재단법인 부동산유통 근대화센터가 국가표준 REINS시스템을 구축하고 전 국을 4 개 부동산유통지역으로 세분화(Figure 3)하고 각 지역별 부도안유통기구를 지정하여 각 지역기구별 매물 $\mathrm{DB}$ 를 수집 및 관리하도록 하였다.

이상과 같이 중개사협회와 국가 주관부처 간 협력 을 통해 궁극적으로는 반관 · 반민의 부동산정보유통 기구를 설립하여 선진화시스템을 구현해야 하는 논리 적 근거는 다음과 같다.

첫째, 민간부문에 해당하는 중개사협회의 거래정보 망(KREN)과 국가시스템이 보유한 공부정보를 직접 연결하는 것은 국가정보망 체계상 및 정보보호에 관 한 제도적 측면에서 현실적으로 불가능하다.

둘째, 공인거래정보망 지정에 관한 기존 법제도('공 인중개사의 업무 및 부동산거래신고에 관한 법률 제 24조) 상 국가는 원천적으로 지정된 가관에 예산지원 의무가 없어, 협회 입장에서는 보다 현실적인 예산 확 보 및 운영방안이 절실하다. 따라서 반관 - 반민의 '부 동산거래선진화시스템‘ 구축을 통해 진성 매물정보, 
계약정보, 시세정보, 실거래정보, 시장동향분석정보 등 다양한 재가공정보를 시장에 유통하여 안정적이고 지속가능한 수익기반을 확보할 수 있다.

셋째, 성공적인 부동산정보유통체계(즉, '부동산거 래선진화시스템')는 원칙적으로 민간성격의 매물정 보망과 공공성격의 공부정보의 융합을 통해서만 가능 한데, 이는 정보시스템의 국가 표준적 구축 및 전국적 배포를 통해 국가와 지역 간 상호운용성이 확보될 때 만 가능하다. 따라서 협회와 국가 주관부처 간 긴밀한 협력을 통해 '국가표준 부동산거래선진화시스템'을 연구개발 및 시범사업 이후 전국 시·도별 반관·반민 의 '부동산정보유통기구'에서 부동산거래 현업에서 활용할 수 있도록 해야 한다.

한편, 중개사협회의 매물정보망이 반관 - 반민의 부 동산거래 선진화시스템의 3대 서브시스템 중 '부동산 정보유통시스템'으로 수렴될 경우, 협회는 다음과 같 이 매우 다양한 수익구조 다변화의 이점을 기대할 수 있다(Figure 8).

첫째, 온라인 매매계약시 계약서에 (가칭)e-공제증 서를 자동 첨부하도록 하여 중개수수료에 정확한 부 동산정보 제공과 안전한 거래지원의 대가로 온라인 공제비용을 추가로 부가할 수 있도록 한다. 다만 e-공 제증서에 관한 법제도 및 정책적 효과 등에 관한 검증 이 선행되어야 한다.

둘째, 협회는 선진화시스템을 기반으로 맴버쉽 비 용과 전자거래 맴버쉽카드 그리고 매달 시스템 접근 에 의한 정보이용수수료(미국의 경우 300 불/월)를 징 수할 수 있다.
셋째, 선진화시스템의 공공거래정보망으로서 신뢰 성을 바탕으로 협회는 전국에 걸친 키박스(Key Box) 사업권을 관할할 수 있다. 키박스사업이란 선진국은 보편적이나 아직 한국에 없는 부동산 유관사업으로서 매도자-매수자-중개사간 동일시간대 매물입지에 모 이자 않아도 중개사가 매수의향자에게 매물을 보여줄 수 있도록 매도자 부동산의 출입구에 열쇠(또는 비밀 번호)보관함을 설치 및 시스템기반 모니터링하는 사 업이다.

넷째, 선진화시스템 상 활동하는 중개사는 거래절 차상 요구되는 법무사, 세무사, 금융전문가 등 각종 자격사 리스트에서 특정 자격사를 지정하는데 대해 일정 수수료를 징수할 수 있다.

\subsection{2 감정평가사 등 기타 자격사 관련}

감정평가사, 법무사 및 세무사 등 기타 자격사 그룹 에게는 선진화시스템을 통해 평가대상 계약정보와 공 부정보로의 접근이 용이해져 부동산감정평가, 법무 및 과세행정 등을 위한 영업기회와 실시간 고급정보 의 취득기회가 대폭 확대된다. 특히, 선진화시스템 기 반의 거래절차 상 가장 먼저 중요한 시세정보를 보다 전문적이고 정확히 제공할 수 있도록 선진화시스템 제공정보와 한국감정원 등의 감정평가시스템을 활용 한 공신력 있는 시세정보 제공기능을 더욱 강화해갈 필요가 있다. 이들 자격사그룹은 이점에 상응하는 대 가로 회비, 정보이용료 납부 및 수익금 일부를 시스템 운영관리비 등으로 일조할 수 있다.

한편, 2013년부터 국민은행에서 감정원으로 이관된

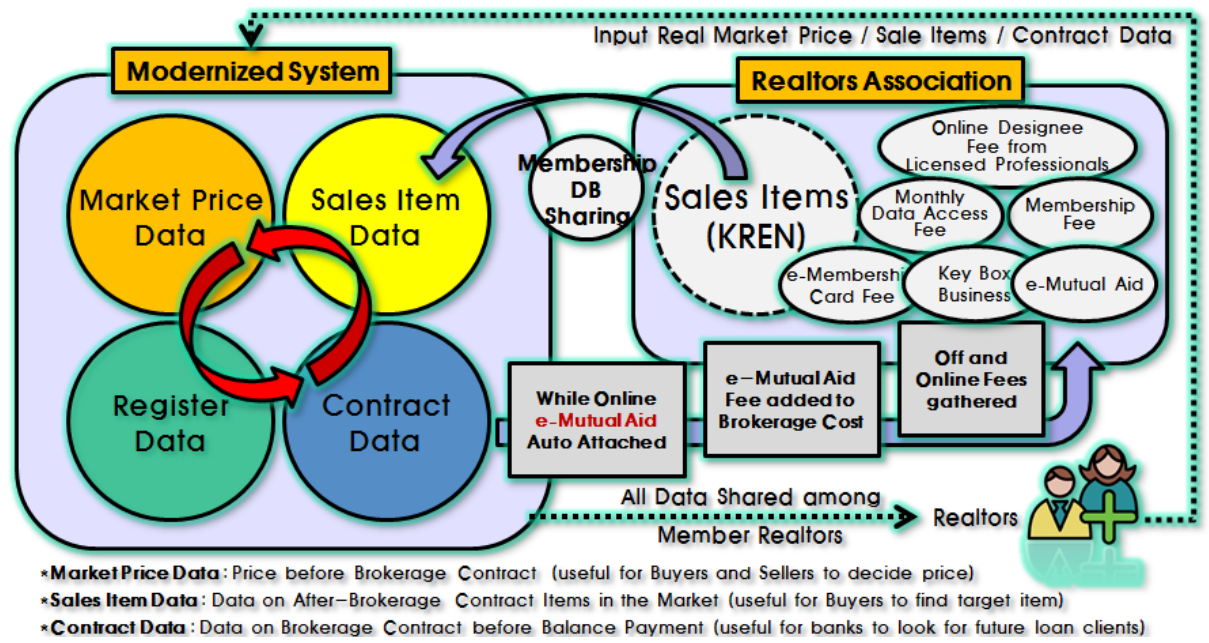

Figure 8. Governance between Realtors Association and Modernized Transaction System 
전국주택가격동향조사 기능은 사실상 선진화시스템 이 완전 정착될 경우 시스템 내에 수렴할 수 있다. 즉, 회원 중개사들을 대상으로 무비용으로 시세정보 취득 이 쉬워지므로, 정부의 고정비용 지출에 의한 시세정 보 취득의 노력은 점차 불필요해질 수 있다.

\subsection{3 금융기관 관련}

국민을 대상으로 한 부동산대출 사업 등을 하는 금 융기관으로서 부동산 감정평가, 시세정보 조사 및 유 통은 중장기적인 관점에서 볼 때 불합리한 것으로 판 단된다. 대신 금융기관 입장에서 미래 고객확보의 차 원에서 가장 가치가 높은 계약정보(즉, 중개사를 매개 로 매수 - 매도인 간 체결된 부동산계약 정보)를 선진 화시스템 기반 유상 제공할 수 있다. 즉, 선진화시스템 으로부터 제공받은 계약정보를 활용하여 부동산 금융 대출을 활성화할 수 있는 정보기반을 제공받을 수 있 다. 한편, 온라인 부동산거래절차 상 금융거래(대출, 지 불, 세금납부 등) 서비스 링크를 유상으로 제공받아 대 출, 대금지불 및 세금납부 등에 활용토록 할 수 있다.

\section{5. 맺음말}

우리나라는 1983년 공인중개사 관련법을 최초로 도 입하여 공인중개사를 중심으로 한 부동산거래문화 발 전에 노력해왔다. 또한 국토교통부는 중개사협회 등 거래정보망 사업자를 일부 지정하여 매물정보의 신뢰 성 및 거래의 투명성 확보에 주력해왔다. 그럼에도 불 구하고 부동산거래 자체에 대한 준법수준과 관행은 대부분 오랜 과거 복덕방 시절의 그것에서 크게 벗어 나지 못한 상황에 있다. 반면, 미국과 일본으로 대표되 는 해외 부동산거래 선진국들을 살펴보면, 부동산거 래 상 중개사의 역할과 위상이 월등하게 높고 중요하 게 인식됨을 알 수 있다. 이러한 결과에는 몇 가지 관 점에서 우리나라와 매우 다른 노력들에 기인한 것임 을 강조하지 않을 수 없다.

무엇보다도 부동산거래 절차상 공인중개사를 핵심 으로 기타 자격사들과 상호관계가 유지되도록 하는 공공표준 부동산거래시스템의 역할을 간과할 수 없 다. 전국중개사협회가 국가 중앙부처와 협력 하에 공 공표준 부동산거래시스템(미국은 MLS, 일본은 REINS 등)을 개발 및 구축하고, 이를 전국 지역협회를 통해 전국에 확산 배포하여 이용하고 있다. 물론 표준시스 템은 공인중개사를 핵심 자격사로 하고 거래절차상 기타 자격사들을 필요한 거래단계에 선정하고 조율하 는 중핵적 역할을 수행토록 구축하였다.
또한 전속중개계약(Exclusive Brokerage Contract) 이 매우 보편화되어 가장 안정적인 부동산거래의 방 편으로 널리 인식되어 있으며, 이는 중개사의 보수확 보의 기회를 보다 투명하게 보장해주고 있다. 한 개의 매물에 대한 다수의 중개사가 연결된 한국의 경우와 달리, 단일 매물당 일인 중개사의 책임중개를 표준거 래시스템을 발판으로 안정적으로 보장해주고 있다. 특히, 우리나라는 현행 거래정보망 지정의 이유가 1994년 도입된 전속중개계약제도를 활성화하기 위한 방편으로 전속거래매물 등록을 전제로 지정된 배경을 갖고 있다. 따라서 일반매물 등재와 포털화 지향만으 로는 지정된 거래정보망의 기능을 성공적으로 수행하 는데 근본적인 제약을 가진다. 즉, 전속중개는 국가지 정 거래정보망 기능화의 전제조건이며, 이는 민관협 력을 통해 부동산거래선진화시스템 공동구축 및 전국 활용을 통해 해결해가야 한다. 이를 통해 전속거래와 일반거래가 국민 선택에 의해 자율적으로 공존 및 발 전할 수 있는 보다 '선진화된 부동산거래문화' 정착에 공동 노력해야 한다.

요컨대, 우리나라 부동산거래 선진화의 방향은 실 제 부동산을 사고 파는 시민들의 입장에서 편리하고 자연스러운 부동산거래절차를 전자상거래로 구현해 낸 표준부동산거래시스템(즉, '부동산거래선진화시 스템')을 목표로 소기의 목적을 달성할 수 있다. 또 그 추진의 실마리는 본 연구에서 언급된 다수의 공공 및 민간부문 부서와 부처들의 협력이 아니고는 사실 상 그 실현이 불가능하다. 오늘날 우리나라 전역에 불 어 닥친 부동산거래행위의 실종사태는 어찌 보면 부 동산시장 자체를 대한 전 국민의 신뢰성과 믿을만한 정보기반의 망실을 방증하는 것일 수도 있다. 일본의 REINS를 개발하게 된 기본정신(일본부도안협회, 2012), "내가 내놓은 매물을 전국에 쉽게 배포할 수 있고, 내 가 원하는 매물을 전국에서 쉽게 찾아볼 수 있게 하 자"는 의지는 어찌 보면 당연한 부동산정보유통의 모 습일지 모른다. 우리나라도 민 - 관 협력적 부동산유통 기구 설립 및 전국표준 부동산거래선진화시스템 개발 과 전국보급은 시점의 문제이지 향후 언젠가는 반드 시 해결하고 넘어가야할 부동산정책 상 불가피한 미 래과업이 아닐까 생각한다.

\section{References}

[1] Chae, H. K; Bang, K. S; Mun, Y. K. 2010, The Analysis of Real Estate Agencies' Selection Behavior Factors on Listing Service, `Residention Environment」, 
Residention Environment Institute of Korea 8(1): 139-154

[2] Cho, C. M; Chung, M. S. 2010. U-City Service Space Realization Strategies in Digital Convergence Era, Journal of Korea Spatial Information Society 18(2):77-88.

[3] Choi, B. H. 2007. The Rationalization Scheme of Exclusive Agency Listing and Transactional Information Network for Real Estate, Doctoral Dissertation, Kangwon Univ.

[4] Choi. I. S. 2001. Study on the Measures for Advancing Real Estate Services and Transaction, Korea Institute of Criminology.

[5] Kim, J. K. 2010. A Study on an Information Service Model for Real Estate Trading, Master's Thesis, Seoul City Univ.

[6] Kim, J. K. 2011, A Study on the Plans to Improve the Real Estate Brokerage, Master's Thesis, Hanyang Univ.
[7] Kim, Y. K. 2009. A Study on the Promotional Strategies of Real Estate Transaction and Information Network System, Master's Thesis, Kyunggi Univ.

[8] Korea Appraisal Board. 1994. Feasibility Study of Real Estate Transactions Information Business Entry, KAB Research Report.

[9] Kwon, S. H; Kim, M. S; Kim. Y. H; Chung. C. S. 1996. Design and Implementation of Realty Trade Information Management System based on WWW, Journal of Korea Spatial Information Society 4(1):75-81.

[10] Mun, Y. K; Yu, S. J. 2005, Real Estate Brokerage Theory, Buyeonsa Publishing Co.

[11] The Real Estate Companies Association of Japan. Real Estate in Japan 2012.

논문접수 : 2013.11.10

수 정 일 : 2013.12.25

심사완료 : 2013.12.30 